\title{
Necessity of ESP (English for Specific Purpose) Courses for Medical and Science Students at Najran University, Saudi Arabia: An Exploratory- cum-remedial Study
}

\author{
Mohammad Owais Khan \\ College of Languages \& Translation, Najran University, Najran, Saudi Arabia
}

\begin{abstract}
English as we know that plays a major role in higher education, Science and technology. It also plays a very essential role in the field of Medicine and other related disciplines because textbooks and journals are mostly written in English. This paper is an attempt to call for ESP courses specially designed to meet the needs of the growing demand of teaching English to Medicine and Science students or to modify the prerequisite course of such professional disciplines i.e. "Preparatory Year Program (PYP)" up to the level of ESP. The present study identifies the students' acuities about the significance of the language skills, their ability in performing those skills, and their preferences regarding the English language course. It also sheds light on the problems in teaching English for specific purpose in Saudi Arabia. This study investigates the challenges encountered in teaching Medicine and Science students in Saudi Arabia and also attempts to answer the following questions: (a) what are the challenges that Medicine and Science teacher face while teaching? (b) What are the causes of these problems and (c) how can such problems be minimized? Finally, the findings of the research suggest some remedial measures and recommendations for improvement.
\end{abstract}

Index Terms-English for Specific Purposes, English for medical students, specific needs, and remedial measures

\section{INTRODUCTION}

The ubiquitous use of the English language is considered international communication or globalization. In this continuous and constant expansion of globalization, English is considered as the language of Science and Technology. In this era of Internet, English is the most commonly used language and it is the only source of communication. Most of the universities all over the world including Arab world introduced ESP courses for Science, Medical and Engineering streams.

In Saudi context, Faculty of Medicine, Engineering and Technology in general and the College of Dentistry at Najran University in particular espouse English as the only medium of instruction. The students enrolled in these faculties face great problems because they are not taught any specific English courses for their discipline. The foundation course or the prerequisite course for these faculties is preparatory year program (PYP) which does not adequately prepare the students to function in accordance with their specialization because they take only language skills courses i.e. (LSRW) Listening, Speaking, Reading and Writing and same approach has been adopted in the prerequisite course at preparatory year program, Najran University. The course books which the students are studying in foundation courses do not fulfill the requirement of ESP. ESP course material in different universities of Saudi Arabia have been selected without taking care of the desired level of proficiency of the students and proper investigation. It has been observed that, course designing and syllabus for ESP should be the first priority. Therefore, this study aims at investigating the students' needs at the College of Dentistry and other professional disciplines, and gives some suggestions and recommendations for the solution of these problems. English has a leading position in science and technology; it is the language of world trade. Therefore, English is the foremost language of business and the necessity of the people who enter in the international market. Consequently, appropriate and useful requirements must be kept in mind while designing ESP syllabus and selecting teaching materials.

\section{LITERATURE REVIEW}

English for Specific Purposes (ESP) is one of the most growing areas of EFL for the last several decades. It is one of the most active branches of Applied Linguistics. ESP is the emergence of English as a world language, and is a necessity for Science, Engineering, and Technology professionals to cope with the different teaching situations and needs. Let's start with some definitions of ESP by different authors such as:

Paltridge \& Starfield, (2013), defined that "English for Specific Purposes (ESP) is a learner-centered approach to teaching English as an additional language, which focuses on developing communicative competence in a specific 
discipline such as academics, accounting, agrology, business, IT, teaching, and engineering. Unlike many other research areas in theoretical and applied linguistics, ESP has been, at its core, a practitioners' movement, devoted to establishing, through careful research, the needs and relevant discourse features for a targeted group of students."

Dudley, E.T. \& John. M. (1998) extended definitions of ESP in terms of 'absolute and variable' characteristics are as follows:

Absolute Characteristics

1. ESP is defined to meet specific needs of the learners.

2. ESP makes use of underlying methodology and activities of the discipline it serves.

3: ESP is centered on the language appropriate to these activities in terms of grammar, lexis, register, study skills, discourse and genres.

Variable Characteristics:

(1) ESP may be related to or designed for specific disciplines.

(2) ESP may use, in specific teaching situation, a different methodology from that of general English.

(3) ESP is likely to be designed for adult learners either at a tertiary level institution or in a professional work situation. It could, however, be for learners at secondary school level.

(4) ESP is generally designed for intermediate or advanced students.

(5) Most ESP courses assume some basic knowledge of the language systems.

Hutchinson et el. (1987) rightly says that "ESP is an approach to language teaching in which all decisions as to content and method are based on learners' reason for learning."

Munby, J. (1978) remarks that "ESP courses are those where the syllabus and materials are determined in all essentials by the prior analysis of the communication needs the learner, rather than by the non-learner-centred criteria such as teacher's or institution's predetermined preference for General English or for treating English as part of a General Education."

Habtoor, A.H. (2012) suggests that "ESP is a unique domain of teaching and learning English in the sense that materials and methods are set in accordance with the learner's needs. In this regard, ESP is seen as a more focused domain of teaching English."

Alsubie, S. (2016) asserts that "English for Specific purposes (ESP) is an approach to English language teaching to which the language is taught for a specific utilitarian purposes."

Sifakis, N.C. (2003) avers that "It is important to remember that the ESP domain is characterized by a wide diversity — different learners, different classes, different needs, different syllabi, different teachers. While it is crucial not to lose sight of this diversity."

Christopher, W. (1914) gives a brief history of ESP that "The study of specialized discourse has burgeoned over the last twenty years or so, and, with English becoming ever more the lingua franca of this globalized world, English for Specific Purposes has rapidly assumed a key position in language studies in general. This has coincided with an increasingly "functionalist" approach to education in general, with the emphasis ever more on the acquisition of skills that can be utilized in a professional context, at the expense of a more theoretical, idealistic perspective, which views education as an intellectual endeavor concerned with an individual's personal and cultural development as a whole.

He further defines the plethora of subfields of ESP - each with its own acronym - has been spawned, an indication of how vigorously the field of ESP has been ramifying. These subfields include:

- English for Science and Technology (EST)

- Vocational English as a Second Language (VESL)

- English for Vocational Purposes (EVP)

- English for Specific and Academic Purposes (ESAP)

- English for Professional and Academic Purposes (EPAP)

- English as a Lingua Franca in Academic Settings (ELFA)

- English for Occupational Purposes (EOP)

- English for Business Communication (EBC)

- English for Sociocultural Purposes (ESCP)

- English for General Business Purposes (EGBP)

- English for Medical Purposes (EMP)

- English for Legal Purposes (ELP)

- English for Academic Legal Purposes (EALP)

- English for Research Publication Purposes (ERPP).

And in this digital era, recent additions have included:

- electronic Business English (e-BE)

- electronic Medical English (e-ME).

Basturkmen, (2010) defines the branches of ESP that "ESP has three main branches; these are English for Science and Technology (EST), English for Business and Economics (EBE), and English for Social Studies (ESS). These 
branches were further divided into sub-branches of three categories: English for Academic Purposes (EAP), English for Occupational Purposes (EOP), and English for Vocational Purposes (EVP)."

Richards and Schmidt (2010) defines ESP as "The role of English in a language course or programme of instruction in which the content and aims of the course are fixed by the specific needs of a particular group of learners. For example courses in English for academic purposes, English for science and technology and English for Nursing. These courses may be compared with those, which aim to teach general language proficiency, English for general purposes.

\section{PURPOSE OF THE STUDY}

The study investigates the opinions of the students as well as the teachers at the College of Dentistry at Najran University that foundation course i.e. Preparatory Year Program (PYP) which Najran University provides as a prerequisite is not enough for Science, Medicine and other professional disciplines. A course of ESP should be designed especially for such disciplines to meet the basic requirements, as well as to make the students active and motivated in learning process. The main objective of the study is to explore the necessity of ESP courses. The study also aims at achieving a tolerable view about the effectiveness of the ESP courses. It also investigates to what extent the ESP helps students learn English for specific purposes. The study also answers the following questions:

1) What does a teacher ponder about teaching of English for Science and Medicine Students?

2) To what extent does the ESP meet the students' needs?

3) What are the challenges that teachers face while teaching?

4) What are the causes of these problems?

\section{Statement of The STUdy}

The present study examines problems of ESP Courses at Najran University. English has a special significance to students, especially those who are in Science and Medicine streams; there are problems for both teachers and students. Teachers of English finds problems and hindrances while teaching ESP courses because the terminologies used in science and medicine streams are entirely different from English vocabulary. Another obstacle is the teachers' lack of contextual knowledge in teaching such courses. Consequently, the English courses provided by the university do not achieve the target objectives, and this makes disgruntlement for both students and teachers.

\section{METHODOLOGY}

The methodology of the study is concerned with how the study is carried out.

\section{A. Research Tools and Data Collection Procedure}

1. Teachers' Questionnaire

2. Students' Questionnaire and

3. Class observation

The corpus of the data for analysis was collected from 68 students in the Faculty of Dentistry at Najran University and 20 teachers of English language who teach in this faculty. All the students and teachers have been taken as the participants of the study. Teachers were requested to complete the questionnaire specially designed for them. Also the students were asked to fill out the questionnaire. Two separate questionnaires for teachers and students employed a fivepoints Likert-scale ranging from "strongly agree" to "strongly disagree" were used. The students' questionnaire had been distributed to over 120 participants and out of them only 68 had returned completely filled questionnaire in two weeks' time. All 68 completed samples were used for the study.

\section{B. Limitations of the Study}

The present research limits only male students of Dental College, Najran University, Najran, Kingdom of Saudi Arabia. Female, Engineering and other science streams of Najran University have not been included in this study because of the gender separation in education system in the country.

\section{Results and Discussion}

The most perceptible result from the questionnaire is the participants' eagerness to join the ESP course that will benefit them in their studies. The study outcome shows the importance of ESP course that plays an important role in teaching Science and Medicine students. The majority of the participants have agreed in getting an extra foundation course based on ESP, which will help them to pursue their higher studies. The agreement of the participants for taking an ESP course before their Science and Medicine course, makes sense because English in Arab world in general and Saudi Arabia in particular has a palpable stimulus. However, the difficulty for these students, especially the ones who are weak in English lies in acquiring their own Science and Medicine subjects.

In the results, both "Agree" and "Strongly Agree" were considered as positive responses in favour of questionnaire's item or statement while "Disagree" and "Strongly disagree" considered as negative responses. 
Table 1 below display participants' responses to the questionnaire items related to the personal details of the participants from item no. 1-4. Item (1) "College" shows that all the participants included in this study are from Dental College. Item (2) "Age" describes the age of the participants, so 21 of them are in the age of 16-20, 33 are in the age of 21-25 while 11 of them are above 30 years of age. Next item of this table "Unban/Rural" tells us that the majority of the students i.e. 42 out of 68 belong to urban areas whereas 23 belong to rural areas.

\begin{tabular}{|l|l|l|l|l|l|l|}
\hline \multicolumn{7}{|l|}{ TABLE 1 } \\
\hline \multicolumn{7}{|l|}{ PERSONAL DEtAILS OF THE INFORMANTS (ITEM NO. 1-4) } \\
\hline Participants & College & Age & \multicolumn{2}{l|}{ Urban/Rural } \\
\hline & Dental College & $16-20$ & $21-25$ & above 30 & Urban & Rural \\
\hline 68 Students & 68 & 21 & 33 & 11 & 42 & 23 \\
\hline
\end{tabular}

The following Chart No.1 shows the various components of students' profile and their numbers.

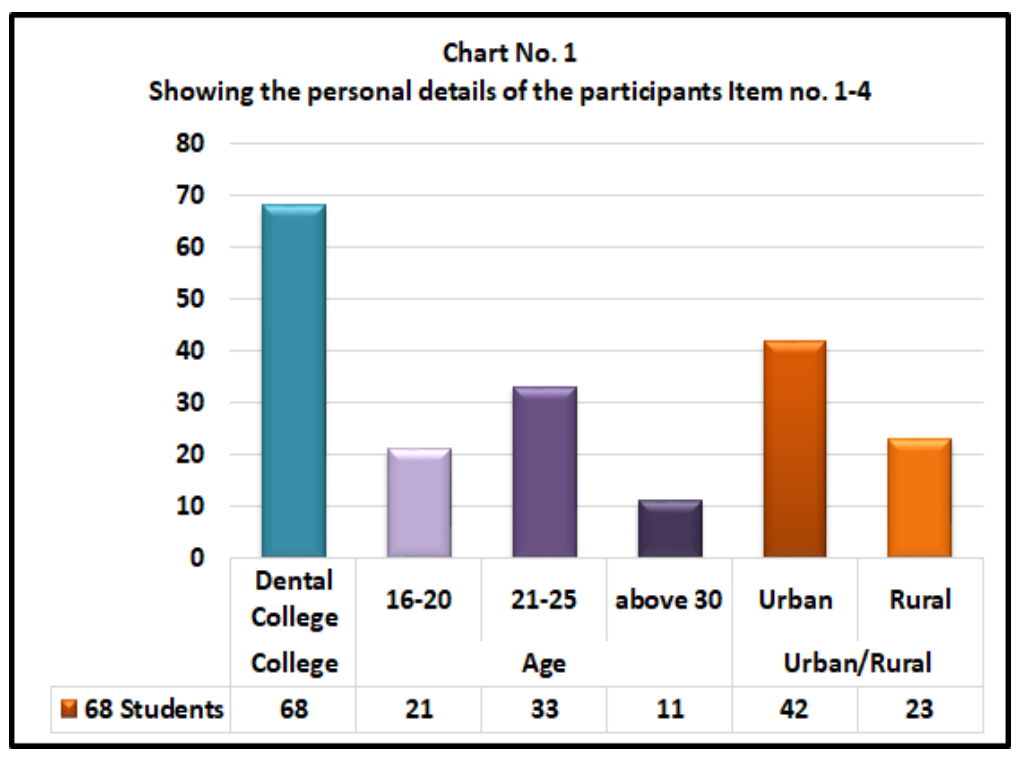

Table 2 below displays participants' responses to the questionnaire items regarding English language and mother tongue of the participants from item 5-8. Item (5) "I passed my High School from Arabic/English/Other than Arabic" shows that all the participants have passed their high school from Arabic Medium School. Similarly, item (6) "What is your mother tongue?" highlights that the mother tongue of all the students was Arabic. Next item "How important is English to you?" tells us that $100 \%$ students agreed that English is very important for them. Last item of this table i.e. "Your College should be in English or Arabic medium?" around 30 students said that their college should be in Arabic medium while the other 38 of them were not with the statement and they said that their college should be in English medium.

\begin{tabular}{|c|c|c|c|c|c|c|c|c|c|c|}
\hline \multicolumn{11}{|c|}{ TABLE 2} \\
\hline \multicolumn{11}{|c|}{ SHOWING STUDENTS' RESPONSES REGARDING ENGLISH LANGUAGE \& MOTHER TONGUE (ITEM NO. 5-8) } \\
\hline \multicolumn{3}{|c|}{$\begin{array}{l}\text { I passed my High School } \\
\text { from }\end{array}$} & \multicolumn{3}{|c|}{$\begin{array}{c}\text { What is your Mother } \\
\text { Tongue? }\end{array}$} & \multicolumn{3}{|c|}{$\begin{array}{c}\text { How important is English to } \\
\text { you? }\end{array}$} & \multicolumn{2}{|c|}{$\begin{array}{c}\text { Your college should be in English } \\
\text { or Arabic medium. }\end{array}$} \\
\hline$\frac{0}{\frac{0}{0}}$ & $\begin{array}{l}\tilde{5} \\
: 00 \\
\text { ज्ञ }\end{array}$ & 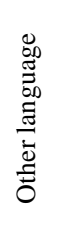 & $\frac{.0}{\frac{\pi}{4}}$ & $\begin{array}{l}\tilde{5} \\
: 00 \\
\text { ज्ञ }\end{array}$ & 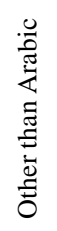 & 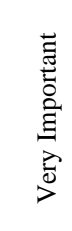 & 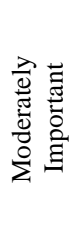 & 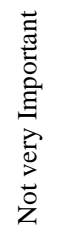 & 愛 & $\begin{array}{l}\overline{0} \\
\overline{6} \\
60 \\
\text { 品 }\end{array}$ \\
\hline 68 & 0 & 0 & 68 & 0 & 0 & 68 & 0 & 0 & 30 & 38 \\
\hline
\end{tabular}

The following Chart No. 2 shows the various components of students' profile, their numbers \& percentage (\%): 


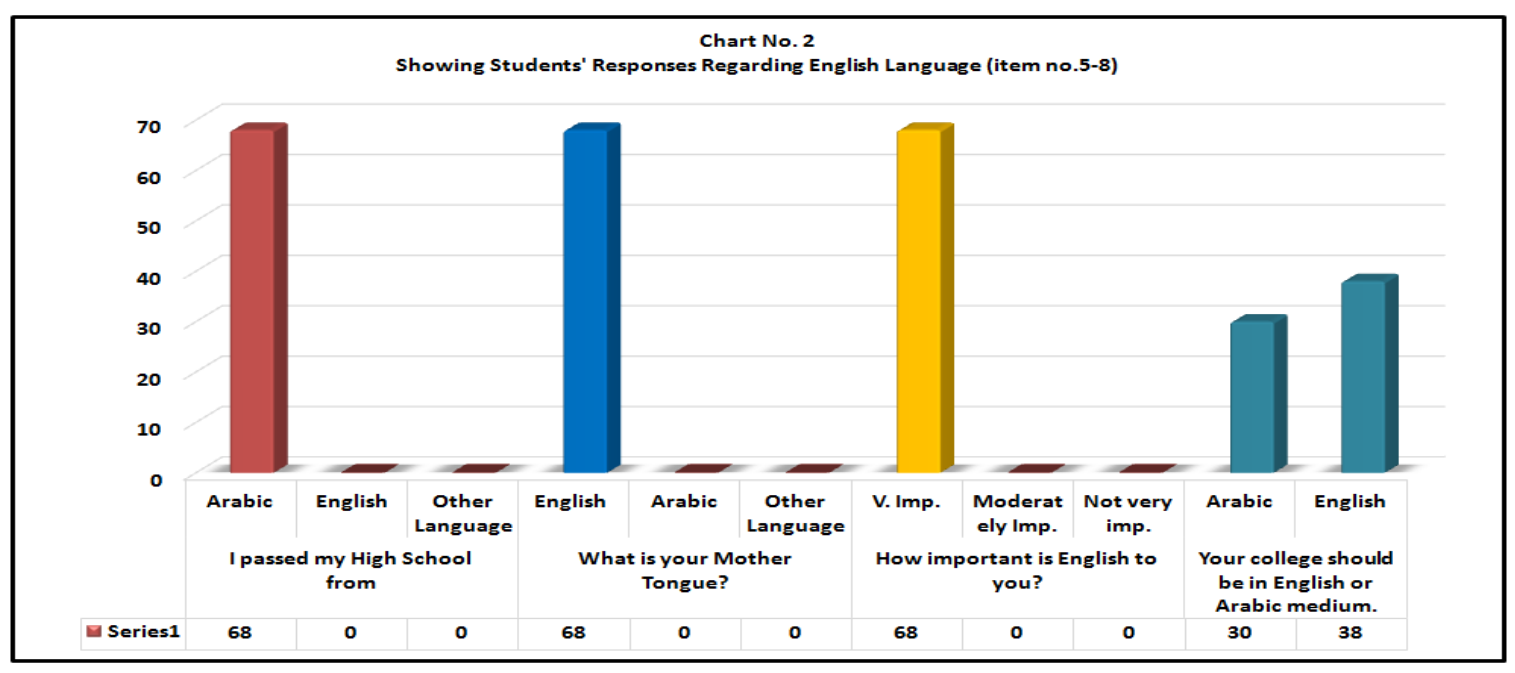

Table 3 below shows the percentages of the students' remarks on the statements related to the level of English they have already acquired. The first statement i.e. "I think English is a very difficult language." $34 \%$ of the students agreed, $37 \%$ neither agreed nor disagreed while $29 \%$ of them disagreed. $56 \%$ students agreed on the statement that "they want to learn English because their English is very poor, " only $31 \%$ of them disagreed. Almost $62 \%$ students were with this statement that "their English is poor because they came from Arabic medium background." 30\% of them disagreed with the statement. It is clear that the majority of the students think that they face language problems regarding English as a medium of instruction whereas $37 \%$ students believe that they do not have problem with English medium. Almost $82 \%$ of the students think that they speak English in the classroom while $18 \%$ of them disagreed. 56\% students feel hesitant to speak in the classroom, 24\% disagreed while $20 \%$ of them were neutral. In the last statement of table 3 , $100 \%$ students agreed that "their teachers speak English in the classroom." Thus, we can say that the majority of the students think that they face language problems regarding English as medium of instruction, their English is poor, and they are hesitant to speak English in the classroom.

\begin{tabular}{|c|c|c|c|c|c|}
\hline \multicolumn{6}{|c|}{$\begin{array}{c}\text { TABLE } 3 \\
\text { SHOWING THE PERCENTAGES OF THE STUDENTS' REMARKS ON THE STATEMENTS RELATED TO THE LEVEL OF ENGLISH THEY } \\
\text { HAVE ALREADY ACQUIRED (ITEM NO. 9-15) }\end{array}$} \\
\hline Statements & $\begin{array}{l}\text { Strongly } \\
\text { agree }\end{array}$ & Agree & $\begin{array}{l}\text { Neither agree } \\
\text { nor disagree }\end{array}$ & Disagree & $\begin{array}{c}\text { Strongly } \\
\text { agree }\end{array}$ \\
\hline I think English is a very difficult language. & 3 & 31 & 27 & 22 & 7 \\
\hline I want to learn English because my English is very poor. & 21 & 35 & 134 & 25 & 6 \\
\hline $\begin{array}{l}\text { My English is poor because I came from Arabic medium } \\
\text { background. }\end{array}$ & 40 & 22 & 18 & 21 & 0 \\
\hline $\begin{array}{l}\text { I face language problems regarding English as medium } \\
\text { of instruction. }\end{array}$ & 28 & 44 & 10 & 7 & 10 \\
\hline I speak English at my college. & 35 & 47 & 9 & 9 & 0 \\
\hline I hesitate to speak English in classroom. & 18 & 44 & 15 & 18 & 6 \\
\hline Teachers speak only English in the classroom. & 28 & 72 & 0 & 0 & 0 \\
\hline
\end{tabular}

The following Chart No. 3 shows the percentage of the students' remarks on the statements related to the level of English they have already acquired (item no. 9-15):

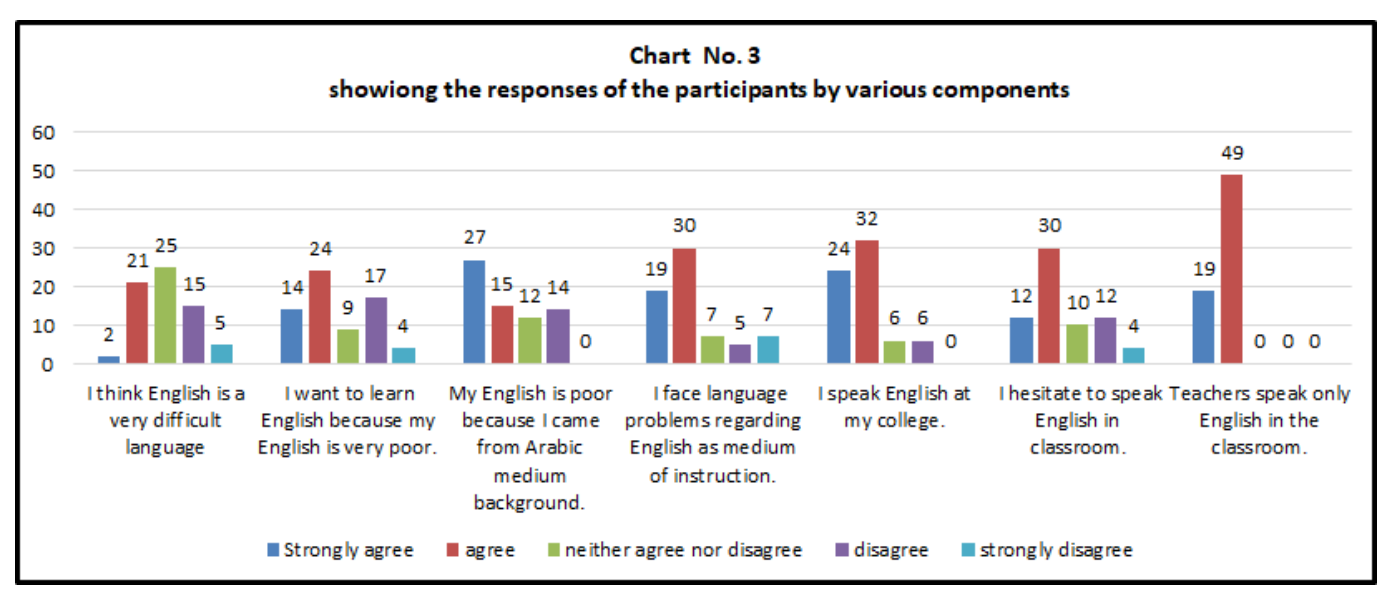


Table 4 below shows the percentages of the students' responses on the statements related to the requirement of an ESP course. The first item in table 4 i.e. "I don't apprehend Science and Medicine books written in English because my English is poor." $79 \%$ of the students agreed on this statement and only $21 \%$ of them disagreed. On the second statement $87 \%$ students agreed that "they get stressed about taking tests and examination in English." only $19 \%$ of them disagreed while only 3\% neither agreed nor disagreed. Almost $83 \%$ students were with the statement that "they need an ESP Course before joining faculty of Medicine." $15 \%$ of them disagreed with this statement. It is clear that the majority of the students think that they face language problems regarding English as medium of instruction whereas $37 \%$ students believe that they do not have problem with English medium. Almost $82 \%$ of the students thought that they speak English in the classroom while 18\% of them disagreed. $83 \%$ students felt that foundation course of English (Preparatory Year) is not enough to meet the requirement of Science and Medicine course, 3\% neither agreed nor disagreed while $15 \%$ disagreed. Almost $87 \%$ students agreed that they need extra time to study English simultaneously with their Science/ Medicine course. In the last statement of table 4, 87\% of the students agreed that "a course of ESP for Sciencel Medicine should start in the same faculty." According to the said table, the majority of the students think that a course of ESP should be launched in the Science/ Medicine faculties simultaneously with the Science and Medicine subjects.

\begin{tabular}{|l|c|c|c|c|c|}
\hline \multicolumn{7}{|c|}{ TABLE 4 } \\
\hline \multicolumn{1}{|c|}{ SHOWING THE PERCENTAGE OF STUDENTS' RESPONSES ON THE FOLLOWING STATEMENTS. } \\
\hline & $\begin{array}{c}\text { Strongly } \\
\text { agree }\end{array}$ & Agree & $\begin{array}{c}\text { Neither agree nor } \\
\text { disagree }\end{array}$ & Disagree & $\begin{array}{c}\text { Strongly } \\
\text { disagree }\end{array}$ \\
\hline $\begin{array}{l}\text { I don't apprehend Science and Medicine books } \\
\text { written in English because my English is poor. }\end{array}$ & 29 & 50 & 0 & 21 & 0 \\
\hline $\begin{array}{l}\text { I get stressed about taking tests and } \\
\text { examination in English. }\end{array}$ & 12 & 66 & 3 & 4 & 15 \\
\hline $\begin{array}{l}\text { I need an ESP Course before joining faculty of } \\
\text { Medicine. }\end{array}$ & 9 & 74 & 3 & 15 & 0 \\
\hline $\begin{array}{l}\text { Foundation course of English (Preparatory } \\
\text { Year Program) is not enough to meet the } \\
\text { requirement of Science and Medicine course. }\end{array}$ & 35 & 47 & 3 & 15 & 1 \\
\hline I need extra time to study English. & 40 & 47 & 3 & 15 & 1 \\
\hline $\begin{array}{l}\text { An ESP course should be compulsory for each } \\
\text { and every student who joins Science and } \\
\text { Medicine courses. }\end{array}$ & 50 & 37 & 3 & 10 & 0 \\
\hline
\end{tabular}

The following Chart No. 4 shows the percentage of the students' responses on the statements related to the requirement of an ESP course. (item no. 16-21):

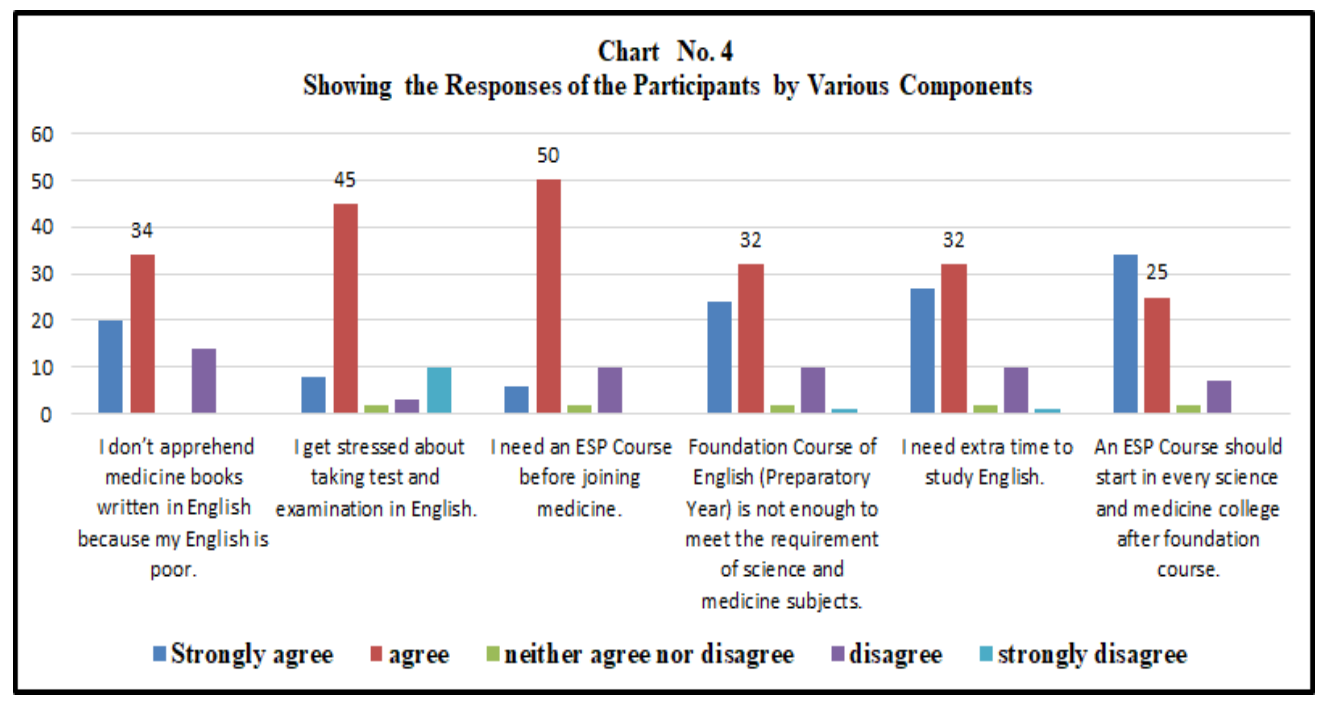

\section{E. Analysis of the Teachers' Questionnaire}

A separate questionnaire was also prepared for the teachers, which was carefully completed by them in two weeks' time. The first section of the Teachers' Questionnaire contained the general problems and difficulties faced by the participants. The opinion of the teachers is shown in the table below: 


\begin{tabular}{|c|c|c|c|c|c|c|}
\hline \multicolumn{7}{|c|}{ TABLE 5 } \\
\hline \multicolumn{7}{|c|}{ SHOWING PERCENTAGE OF THE OPINIONS OF TEACHERS WHO TEACH SCIENCE AND MEDICINE STUDENTS. } \\
\hline \multicolumn{1}{|c|}{ Statements } & $\begin{array}{c}\text { Strongly } \\
\text { agree }\end{array}$ & Agree & $\begin{array}{c}\text { Neither agree } \\
\text { nor Disagree }\end{array}$ & Disagree & $\begin{array}{c}\text { Strongly } \\
\text { disagree }\end{array}$ \\
\hline a) & Students have limited knowledge of English. & 35 & 49 & 4 & 6 & 6 \\
\hline b) & $\begin{array}{l}\text { Students face difficulties in framing sentence } \\
\text { structures. }\end{array}$ & 44 & 47 & 0 & 3 & 6 \\
\hline c) & $\begin{array}{l}\text { Students always confuse (overlap) with } \\
\text { English and Arabic structures. }\end{array}$ & 50 & 48 & 0 & 2 & 0 \\
\hline d) & $\begin{array}{l}\text { Students are unable to understand their } \\
\text { Medicine/Science subjects. }\end{array}$ & 38 & 42 & 6 & 10 & 4 \\
\hline e) & $\begin{array}{l}\text { They take help of their teachers while doing } \\
\text { class task. }\end{array}$ & 45 & 25 & 10 & 15 & 5 \\
\hline
\end{tabular}

The above table shows the percentages of opinion of the teachers on the statement (a) of the questionnaire that $84 \%$ of the teachers agreed on the statement that "students have limited knowledge of English," $12 \%$ disagreed on this statement while only $4 \%$ of them neither agreed nor disagreed. Under item (b) "students face difficulties in framing sentence structures" $91 \%$ of the teachers agreed and only 9\% disagreed. Under item (c) almost 98\% teachers were in the favour of the statement that "students always confuse (overlap) with English and Arabic structures," whereas only $2 \%$ of them disagreed. It is clear that the majority of the teachers have the opinion that students always confuse or overlap with English and Arabic. Item (d) of the questionnaire shows that $80 \%$ teachers were in favour of the statement, $14 \%$ disagreed whereas only $6 \%$ neither agreed nor disagreed. Under statement (d) $70 \%$ of the teachers think that "students take teachers help while doing class task”, 20\% of them disagreed while 10\% neither agreed nor disagreed. According to the above table the majority of the teachers think that students of Science and Medicine have limited knowledge of English and they always confuse or overlap with English and Arabic Structures.

The following Chart No. 5 shows the percentage of opinions of the teachers on the statements related to the general problems and difficulties of English faced by the participants of the study (from statement a-e of the questionnaire):

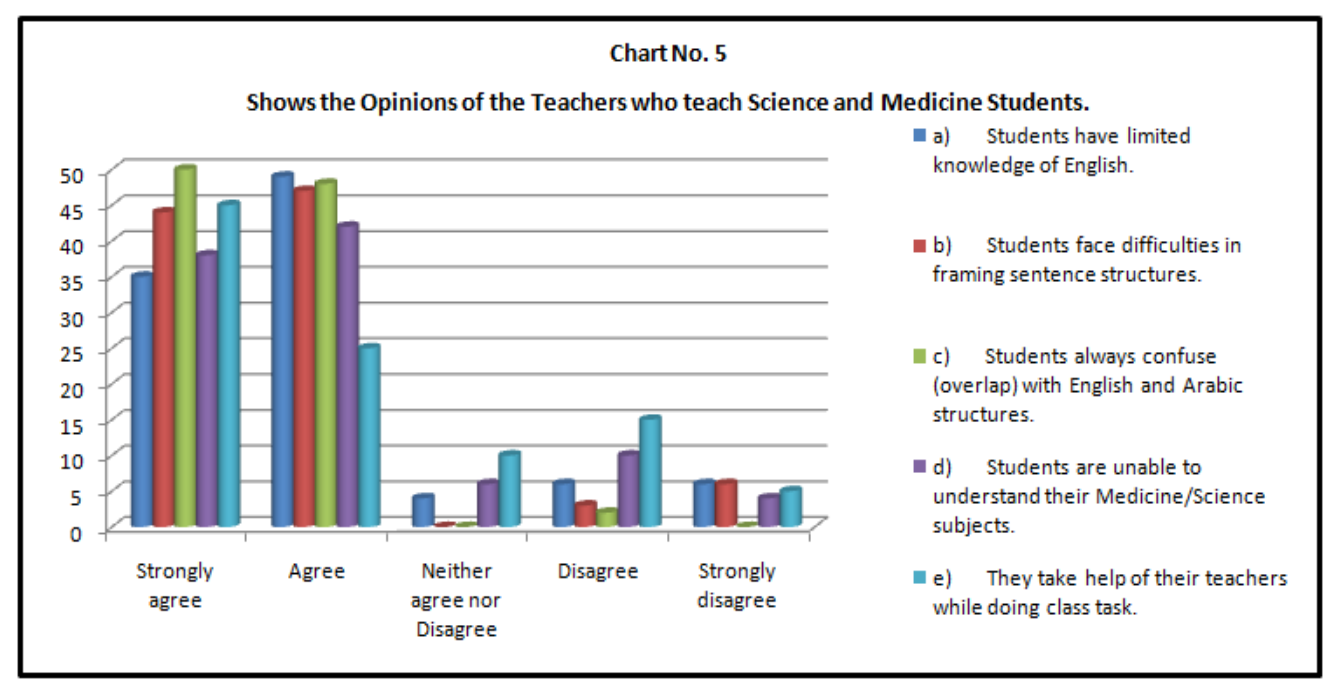

The table No. 6 below shows the percentages of opinion of the teachers on the statements regarding the problems of spelling, Vocabulary and Grammar of the students. Under Item (f) of the questionnaire 44\% of the teachers agreed on the statement that "students speak sentences which are not related to the topic," $41 \%$ disagreed on this statement while only $15 \%$ of them neither agreed nor disagreed. In item (g) "teachers explain the topic to the students in Arabic" $34 \%$ of the teachers agreed, $51 \%$ disagreed whereas $15 \%$ of the teachers neither agreed nor disagreed. It is clear that in the above two statements the opinion of the teachers was negative. Under item (h) almost $93 \%$ teachers were in favour of the statement that "students discuss their problems with the teachers," whereas only $7 \%$ of them disagreed. It is clear that the majority of the teachers had the opinion that students always discuss their problems with the teachers. Item (i) of the questionnaire i.e. "Students are weak in spelling and vocabulary," 90\% teachers were in favour of the statement and only $10 \%$ disagreed. Under statement (j) $31 \%$ of the teachers agreed that "students use proper language in their speaking and writings," $66 \%$ of them disagreed while 3\% neither agreed nor disagreed. Under item (k) of the teachers' questionnaire $37 \%$ of the teachers agreed, $60 \%$ percent of them disagreed whereas only $3 \%$ neither agreed nor disagreed. According to the following table most of the teachers disagreed with the statements (i) and (j) that spelling and vocabulary of the students is very weak and they do not use proper language in their speaking and writing. 


\begin{tabular}{|c|c|c|c|c|c|c|}
\hline \multicolumn{7}{|c|}{ TABLE 6} \\
\hline \multicolumn{7}{|c|}{ SHOWING THE RESPONSES OF TEACHERS WHO TEACH SCIENCE AND MEDICINE STUDENTS. } \\
\hline & Statements & $\begin{array}{c}\text { Strongly } \\
\text { agree }\end{array}$ & Agree & $\begin{array}{l}\text { Neither agree } \\
\text { nor Disagree }\end{array}$ & Disagree & $\begin{array}{l}\text { Strongly } \\
\text { disagree }\end{array}$ \\
\hline f) & $\begin{array}{l}\text { They speak sentences that are not } \\
\text { related to the topic. }\end{array}$ & 25 & 19 & 15 & 35 & 6 \\
\hline g) & $\begin{array}{l}\text { Teachers explain the topic to } \\
\text { students in Arabic. }\end{array}$ & 15 & 19 & 15 & 45 & 6 \\
\hline h) & $\begin{array}{l}\text { Students discuss their English } \\
\text { language problem with the teachers. }\end{array}$ & 48 & 45 & 0 & 5 & 2 \\
\hline i) & $\begin{array}{l}\text { Students are weak in spelling and } \\
\text { vocabulary. }\end{array}$ & 43 & 47 & 0 & 4 & 6 \\
\hline j) & $\begin{array}{l}\text { Students use proper language in their } \\
\text { speaking and writings. }\end{array}$ & 19 & 12 & 3 & 31 & 35 \\
\hline k) & They speak and write correct tenses. & 20 & 17 & 3 & 30 & 30 \\
\hline
\end{tabular}

The following Chart No. 6 shows the percentage of opinions of the teachers on the statements regarding the problems of spelling, Vocabulary and Grammar of the students (from statement f-k of the teachers' questionnaire):

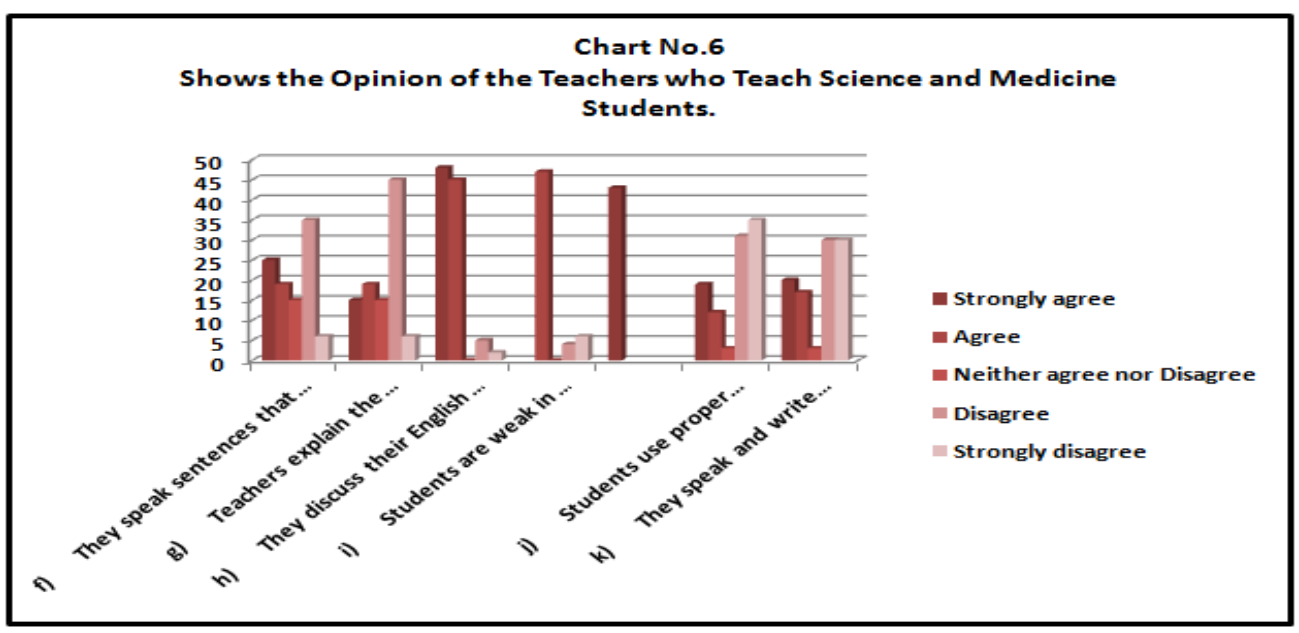

The table No. 7 below shows the percentages of opinion of the teachers' questionnaire regarding the introduction of a new ESP course. Under item (1) 37\% teachers agreed, 60\% disagreed while 3\% neither agreed nor disagreed on the statement "students are always depended on the teacher's assistance in comprehending their subjects." In item (m) "students expect teachers to present the points of the subject explicitly," $89 \%$ of the teachers agreed and only $11 \%$ disagreed. It is clear that in the above two statements the opinion of the teachers was positive. Under item (n) almost $87 \%$ teachers were in favour of the statement that "Students are always eager to learn English," whereas $23 \%$ of them disagreed. Item (o) of the questionnaire i.e. "students can improve their English level after attending a separate English course," $96 \%$ teachers were in favour of the statement and only $4 \%$ disagreed. It is clear that the majority of the teachers have the opinion that students can improve their English level after taking an extra course. Under statement (p) 95\% of the teachers agreed that "students need an ESP course which will be helpful in understanding their Science and Medicine subjects," $5 \%$ of them disagreed. According to the table below majority of the teachers agreed with the statements that students need an ESP course for understanding their Science/ Medicine subjects as well as for improvement of their English level.

\begin{tabular}{|l|c|c|c|c|c|c|}
\hline \multicolumn{7}{|c|}{ TABLE 7 } \\
\hline QUESTIONNAIRE FOR TEACHERS WHO TEACH SCIENCE AND MEDICINE STUDENTS. \\
\hline Statements & $\begin{array}{c}\text { Strongly } \\
\text { agree }\end{array}$ & Agree & $\begin{array}{c}\text { Neither agree } \\
\text { nor Disagree }\end{array}$ & Disagree & $\begin{array}{c}\text { Strongly } \\
\text { disagree }\end{array}$ \\
\hline $\begin{array}{l}\text { 1) Students are always depended on the teacher's } \\
\text { assistance in comprehending their subjects. }\end{array}$ & 20 & 17 & 3 & 30 & 30 \\
\hline $\begin{array}{l}\mathrm{m}) \quad \text { Students expect teachers to present the points of the } \\
\text { subject explicitly. }\end{array}$ & 55 & 34 & 0 & 5 & 6 \\
\hline n) Students are always eager to learn English. & 44 & 43 & 0 & 10 & 3 \\
\hline $\begin{array}{l}\text { o) Students can improve their English level after } \\
\text { attending a separate English course. }\end{array}$ & 51 & 45 & 0 & 3 & 1 \\
\hline $\begin{array}{l}\text { p) Students need an ESP course which will be helpful } \\
\text { in understanding their Science and Medicine subjects. }\end{array}$ & 55 & 40 & 0 & 5 & 0 \\
\hline
\end{tabular}


The following Chart No. 7 shows the percentage of opinion of the teachers on the statements related to the introduction of an ELT course for the Science and Medicine students (from statement 1-p of the teachers' questionnaire):

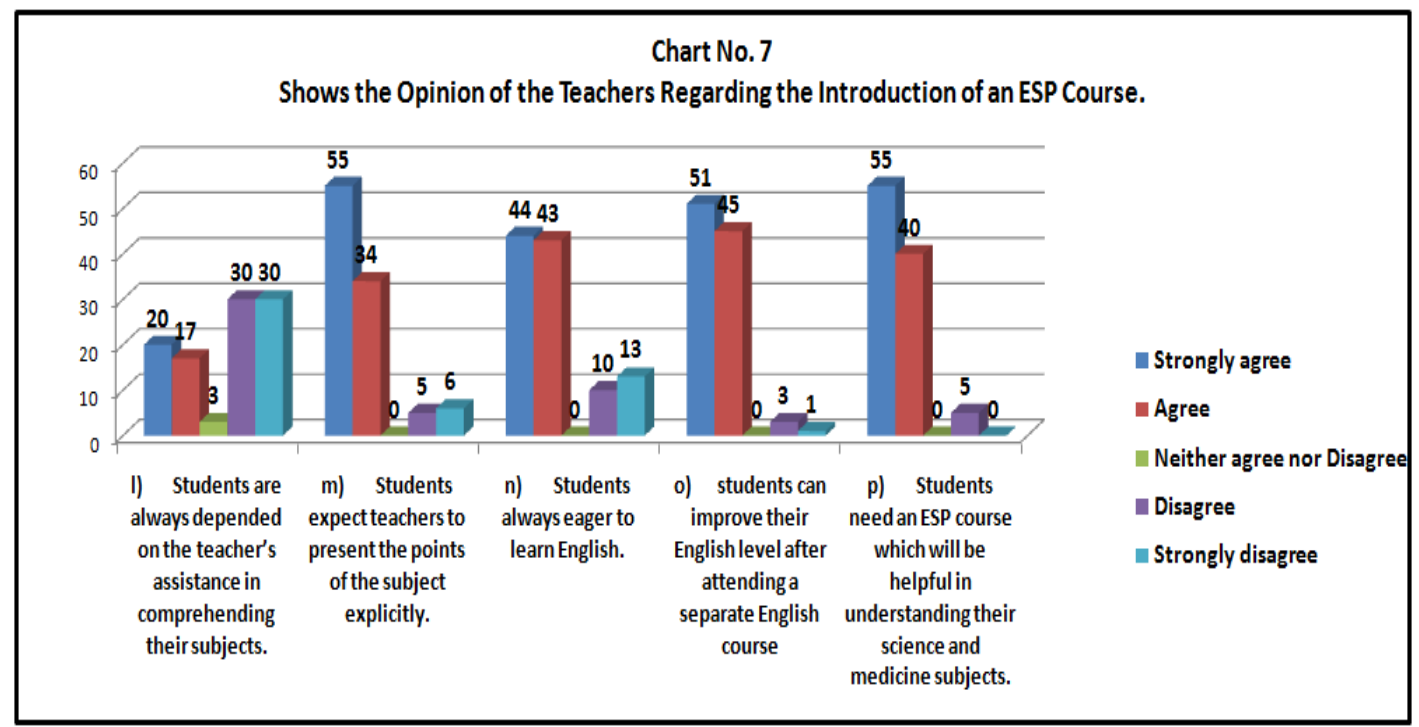

\section{CONCLUSION}

The analysis and interpretation of the data accumulated for answers the questions raised in the mind of the researcher. The results, which were obtained through the administration of the tools during the study are discussed, analyzed and interpreted thoroughly. The analysis of the study finds out some remedial measures to minimize the problems of Medicine and Science students who are weak in English and they are unable to understand their Science/ Medicine teaching material. The investigation has been conducted with the solution that a course of ESP as a prerequisite should be introduced in Medicine, Science and other professional \& vocational faculties. This course should be designed to bridge the gap and uplift the students' language aptitude from existing to the desired level essential for various professional courses. The ESP course will help the students to improve their English as well as to pursue their higher studies.

The investigation has concluded with the following suggestions and recommendations:

Course development should be viewed in a continuous manner. Relevant vocabulary from scientific and professional disciplines should be taught. Teachers should be encouraged to follow CLT approach in their classes. Students should be acquainted with the terminology of their respective discipline. Students should be involved more in English speaking-oriented activities.

\section{REFERENCES}

[1] Alsubie, S. (2016). ESP in Saudi Arabia: A Need for Active Community. International Journal of Language and Linguistics. Vol. 3, No. 5, p.107-111.

[2] Basturkmen, H. (2010). Developing Courses in English for Specific Purposes. Hampshire: Palgrave Macmillan.

[3] Christopher, W. (2014). The Future of ESP Studies: Building on Success, Exploring New Paths, Avoiding Pitfalls », ASp [Online], 66, Online since 01 November 2015, connection on 12 October 2018. p.137-150.

[4] Dudley, E.T. \& John, M. (1998). Developments in English for Specific Purposes: A multi-disciplinary approach. Cambridge University Press.

[5] Hutchinson, T. \& Walter, A. (1987). English for Specific Purposes: A Learner Centered Approach. Cambridge: Cambridge University Press.

[6] Habtoor A.H. (2012). English for Specific Purpose Textbook in EFL Milieu: An Instructor's Perspective Evaluation. International Journal of Linguistics, Vol. 4, No. 3. p. 44-59.

[7] Munby, J. (1978). Communicative syllabus design. Cambridge: Cambridge University Press.

[8] Paltridge, B. \& Starfield, S. (eds.). (2013). The Handbook of English for Specific Purposes. Chichester, UK: Wiley-Blackwell.

[9] Richards J.C., \& Schmdit, R. (2010). Longman dictionary of language teaching and applied linguistics. (4 ${ }^{\text {th }}$ ed). Harlow: Pearson Education Ltd.

[10] Sifakis, N. C. (2003). Applying the Adult Education Framework to ESP Curriculum Development: An Integrative Model. English for Specific Purposes, Vol. 22, No. 2, p.195-211. 


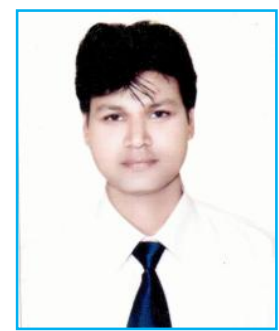

Mohammad Owais Khan was born in Aligarh, Uttar Pradesh, India in 1964. He received his B.A., M.A., and Ph.D degrees in English from Aligarh Muslim University, Aligarh, India, in 1995, 1997 and 2008, respectively. He has done PGCTE (Post Graduate Certificate Course in Teaching English) from EFLU (The English and Foreign Languages University) Hyderabad, India in 1999. In 2001, he joined the Department of English, Aligarh Muslim University, Aligarh, U.P., India as a Lecturer, and in 2009 he joined the Department of English, College of Languages \& Translation, Najran University, Najran, Kingdom of Saudi Arabia as an Assistant Professor. His field of specialization is ELT (English Language Teaching) particularly (ESL/EFL) Second/Foreign Language and Applied Linguistics. His area of interest is Applied Linguistics, Teaching Language through Literature, Phonetics and Phonology, Curriculum and Syllabus Designing. He is a member of the Department Council, College of Languages \& Translation, Najran University. 